\title{
Leaf morphology and anatomy of Jacquinia armillaris Jacq. (Primulaceae) from two coastal Restinga environments
}

\author{
Vinícius Coelho Kuster ${ }^{1}$, Luzimar Campos da Silva², Lucélia Possatti \& Solange Zanotti Schneider ${ }^{3}$ \\ ' Universidade Federal de Goiás, Regional Jataí, Instituto de Biociências, Campus Cidade Universitária, BR 364, km 195, n 3800, 75801-615, \\ Jataí, Goiás, Brazil. \\ ${ }^{2}$ Universidade Federal de Viçosa, Departamento de Biologia Vegetal, Av. P.H. Rolfs, s.n., 36570-900, Viçosa, MG, Brasil. luzimar@ufv.br \\ ${ }^{3}$ Universidade Vila Velha, Rua Comissário José Dantas de Melo, n. 21, 29102-770, Boa Vista, Vila Velha, ES, Brasil.
}

Received on 23.XII.2015

Accepted on 02.IX.2018

DOI 10.21826/2446-8231201873303

ABSTRACT - Jacquinia armillaris occurs in post-beach and rocky outcrops environments, which led to hypothesize that they are morphological and anatomical plasticity in its leaves to inhabit these two coastal formations. Anatomical, histochemical and micromorphometric analyzes were performed to understand the leaf plasticity. The leaf lamina is dorsiventral and hypostomatic, with glandular trichomes. The epidermis is uniseriate, possesses anomocytic stomata and is covered by a thick cuticle and epicuticular wax. The post-beach formation plants had the higher stomatal index and greater stomatal density, however, there are higher leaf size and glandular trichomes density in the rocky outcrop plants. The glandular trichomes are similar in structure to salt glands and may serve to reduce the impact of the local salinity. At first, the two environments present typical coastal environmental conditions, however, specific local characteristics were sufficient to trigger anatomic and morphologic plasticity, particularly associated with the distribution of stomata and leaf size.

Keywords: trichome, post-beach formation, rocky outcrops

RESUMO - Morfologia e anatomia foliar de Jacquinia armillaris Jacq. (Primulaceae) de dois ambientes costeiros de Restinga. Jacquinia armillaris ocorre na formação pós-praia e em afloramentos rochosos, o que levou a hipotetizar que existe plasticidade morfológica e anatômica em suas folhas em virtude da sua presença em duas formações vegetais costeiras. Análises anatômicas, histoquímicas e micromorfométricas foram realizadas para entendimento da plasticidade foliar. A lâmina foliar é dorsiventral e hipoestomática, com tricomas glandulares. A epiderme é unisseriada, possui estômatos anomocíticos, cutícula espessa e cera epicuticular. As plantas da formação pós-praia tiveram maior índice estomático e maior densidade estomática, no entanto, há um maior tamanho foliar e densidade de tricomas glandulares nos afloramentos rochosos. Os tricomas glandulares são semelhantes em estrutura às glândulas de sal e podem atuar na redução da salinidade local. A princípio, os dois ambientes apresentam condições ambientais costeiras típicas, entretanto, características locais específicas foram suficientes para desencadear a plasticidade anatômica e morfológica, particularmente associadas à distribuição dos estômatos e ao tamanho das folhas.

Palavras-chave: afloramentos rochosos, formação pós-praia, tricoma

\section{INTRODUCTION}

The Restinga is an ecosystem associated with the Atlantic Forest (Suguio \& Tessler 1984), and is biologically defined as vegetation on sandy coastal soils in Brazil (Pereira \& Assis 2000), with the types of vegetation being influenced mainly by groundwater level (Scarano 2002). The post-beach formation (Pereira 1990), also called non-floodplain closed shrub lands (Magnano et al. 2011), is remarkable due to its proximity to the sea and its herbaceous and shrubby vegetation (Pereira 1990). Directly in contact with the sea, coastal rocky outcrops associated with Restinga possess predominantly herbaceous plant species that grow on rocks that are resistant to erosion (Leinz \& Amaral 2003, Porembski 2002).

According to Crawford (2008), Scarano et al. (2001) and Scarano (2002), flooding, drought, high salinity, high temperature, constant wind and lack of nutrients have a profound influence on the plant communities of Restinga. Anatomical studies have demonstrated that selection, in response to these environmental conditions, has favored plant species with xeromorphic characters, especially in those that colonize formations near the sea (Andrade 1967, Silva \& Azevedo 2007). Such characters of the leaves include the presence of water storage cells, an epidermis with a thick periclinal cell wall, an abundance of mechanical tissues, and the occurrence of secretory structures, among others (Andrade 1967, Boeger \& Gluzezak 2006, Silva \& Azevedo 2007, Arruda et al. 2009), which contribute to the persistence of these species in Restinga phytophysiognomies.

Jacquinia armillaris Jacq., formerly Jacquinia brasiliensis Mez., is one of the few species that can colonize the post-beach formation and rocky outcrops. It is distributed throughout eastern Brazil (states of Rio de Janeiro, Espírito Santo, Bahia, Alagoas, and Pernambuco), 
northern Venezuela, Colombia, Trinidad and Tobago and the Antilles (Stahl 1992). In Brazil, the species is popularly known as "barbasco", "timbó" or "tingui", and is used in landscaping and for fishing due to the paralyzing effect of the active compounds in its fruits (Rizzini \& Mors 1995, Joly 2002). The species is included in the list of threatened species of the state of Espírito Santo (Kollmann et al. 2007) and of Brazil (IBAMA 2008).

The evaluation of intraspecific structure variation among plants in distinct environments can provide insight into adaptive evolution, since it is believed that non-hereditary variation induced by the environment, such as a phenotypic plasticity, is initially established in a population and then becomes genetically assimilated (Schmalhausen 1949, Ghalambor et al. 2007). In Restinga, for example, structural differences have been reported for Andira fraxinifolia growing in two different phytophysiognomies; plant size and leaf area, among other characteristics, varied between forest and shrub-tree phytophysiognomies (Silva et al. 2016). These morphological adjustments may represent survival strategies that facilitate the optimization of available resources in each environment. Given that only a few studies have addressed structural and ecological features of $J$. armillaris, and that the species occurs in different environments, this study aimed to elucidate the adaptive strategies of this species and document plasticity due to the environmental conditions found in the post-beach formation and coastal rocky outcrops. It is expected that $J$. armillaris will be found to possess leaves with xeromorphic characters that allow it to inhabit environments near the sea where there is high salinity, physiological dryness and nutrient-poor soils. In addition, it is expected that individuals inhabiting rocky outcrops will possess more structural and micromorphometrical leaf traits that limit the loss of water than individuals inhabiting the post-beach formation.

\section{MATERIAL AND METHODS}

Individuals of Jacquinia armillaris Jacq. (Primulaceae) were collected from two environments: post-beach formation (Pereira 1990) in Paulo César Vinha State Park (PCVSP), and rocky outcrops on Setiba beach, both in the town of Guarapari, state of Espírito Santo, Brazil. Voucher material was deposited in the Herbarium of the Universidade Federal do Espírito Santo (VIES) (accession numbers 17,388 and 17,389).

The climate of Guarapari is classified as Aw by the Köppen (1948) system, with hot and rainy summers and dry winters. The average temperature for the coldest month is around $21.2^{\circ} \mathrm{C}$ and that of the warmest month around $25.4^{\circ} \mathrm{C}$. Total annual rainfall ranges from 900 to $1300 \mathrm{~mm}$, with greater precipitation in the summer (Köppen 1948). The rocky outcrops along the coast possess exposed graniticrocky surfaces with some small areas covered with a thin layer of decomposed material. The post-beach formation possesses greater species richness and is located further from the sea in areas of sandy soil. The classification adopted for post-beach formation was based on Pereira (1990). Although Pereira (1990) did not consider rock outcrops to be a phytophysiognomy of the Restinga, this was included in the Restinga because they are associated with it.

Six specimens of Jacquinia armillaris Jacq. were selected for the study: three from the post-beach formation and three from rocky outcrops. Two leaves were collected from the $4^{\text {th }}$ node of each specimen $(\mathrm{n}=12)$, and the leaf blades and petioles were fixed in FAA70 and transferred to $70 \%$ alcohol (Johansen 1940). Leaf primordia and leaves from the $1^{\text {st }}$ node were sectioned for determining tissue origin.

Petiole samples were cross-sectioned using a table microtome (model LPC, Rolemberg and Bhering), clarified in sodium hydroxide (40\%) and stained with $1 \%$ safranin and astra blue (Brito \& Alquini 1996) for anatomical description. For anatomical description and micromorphometry, fragments of the costal middle region of the leaf were embedded in 2-hydroxyethyl methacrylate (Historesin, Leica Instruments, Germany), sectioned (5 $\mu \mathrm{m}$ ) using a rotary microtome (Leica model RM2155) and stained with toluidine blue at $\mathrm{pH} 4.0$ (O'Brien \& Mccully 1981). Photography was carried out using a light microscope (Olympus model AX70TRF) coupled to a U-photo camera system (Spot Insight Colour model 3.2.0). The middle region of the leaf was clarified with $10 \%$ sodium hydroxide solution and incubated in $10 \%$ chloral hydrate until completely transparent, as described by Johansen (1940). The samples were stained with $1 \%$ safranin (Brito \& Alquini 1996) and used for quantification of stomata and glandular trichomes, and classification of the pattern of leaf venation following on Hickey (1979). The epidermis was dissociated following Johansen (1940), and then stained with $1 \%$ safranin and astra blue (Brito \& Alquini 1996).

Histochemical tests using 0.5\% Sudan III (Johansen 1940 ) and $0.02 \%$ ruthenium red (Jensen 1962) were performed to assess the cuticle and other regions of the outer periclinal cell wall, and assist in making micromorphometric measurements.

The length of the petiole and the length and width of the leaf blade were measured $(n=45)$. Micromorphometric measurements of cuticle and leaf thickness were taken from a selection of leaves ( $\mathrm{n}=45$ per environment). Stomatal density and index and glandular trichome density were determined using a leaf from the 4th node $(n=30$ per environment). Stomatal and glandular trichome density were calculated as number per unit area $\left(\mathrm{mm}^{2}\right)$. The stomatal index was estimated considering stomata and epidermal cells of the abaxial surface using the formula proposed by Cutter (1978). Data were acquired using the software Image Pro-Plus 4.1 (Media Cybernetics) and submitted to analyses of variance and t-tests for comparison of means $(\mathrm{p}<0.05)$ on Jump ${ }^{\circledR} 5.0$ (Sas Institute Inc.).

Micromorphological analysis was performed on samples of the middle region of leaves that were dehydrated in an ethyl alcohol series and then critical-point dried (CPD 030 model, Bal-Tec) using liquid $\mathrm{CO}_{2}$. Samples were mounted on stubs and coated with gold using a 
sputter coater (FDU010 model, Bal-Tec). Photographic documentation was performed using a scanning electron microscope (LEO 1430 VP model, Zeiss, Cambridge, England) of the Núcleo de Microscopia e Microanálise (Center for Microscopy and Microanalysis) at UFV.

\section{RESULTS}

The leaves of Jacquinia armillaris are simple, without stipules, symmetrical, coriaceous, brevipetiolate, alternate phyllotaxy, pseudoverticillate, and forming an angle of $45^{\circ}$ with the stem. The length and width of leaf lamina were found to be statistically different between the two phytophysiognomies (Tab. 1). The petiole is approximately $0.2 \mathrm{~mm}$ long.

The epidermis of the petiole has no stomata (Figs. 1AF), and the cells are arranged asymmetrically with anticlinal straight and thick cell walls. Cross-sections revealed that the epidermal cells of plants from the two environments differed in shape and size, and the presence of branched multicellular glandular trichomes limited to the proximal region of the ventral side of the petiole (Fig. 1A). The cuticle is thick and with prominent cuticular flanges (Figs. $1 C, D)$. The parenchymatous cortex has groups of fibers, which occur in greater quantity on the ventral side. The vascular bundle is collateral with a sheath of fibers facing the xylem and phloem (Figs. 1E, F).

In cross-section, the leaf of $J$. armillaris is seen to possess straight to slightly wavy epidermal cells, and glandular trichomes on both surfaces (Figs. 2A-D). The adaxial surface of the epidermis consists of 6-7 sided polygonal ground cells with thick anticlinal walls (Figs. 2A-B), and fewer glandular trichomes than on the abaxial surface (Tab. 1).

The abaxial surface possesses epidermal cells similar to those of the adaxial surface, and stomata and glandular trichomes (Figs. 2C, D). Neighboring epidermal cells are radially disposed to the trichomes. The number of glandular trichomes in the epidermis of both surfaces is significantly higher in plants from the rocky outcrop (Tab. 1).

The epicuticular wax is sparsely distributed as a thin layer on the adaxial surface, and more densely distributed on the abaxial surface forming plaques of irregular shapes (Figs. $3 \mathrm{~A}, \mathrm{~B})$. The glandular trichomes occur in depressions on the epidermis (Fig. 3C), and are seen to produce a secretion with an irregular or crystalline appearance, which, together with the epicuticular wax, cover the leaf surface (Fig. 3D).

The epidermis is uniseriate and consists of both square and rectangular cells (Figs. 4A-B). Below this tissue, on the adaxial surface, there is a hypodermal layer, which is frequently interrupted by groups of fibers (Figs. 4C, D).

The cuticle is thicker on the adaxial surface of leaves from both environments (Tab. 1) and projects between the anticlinal walls forming prominent cuticular flanges (Figs. 4A-B). No significant variation in cuticle thickness was found between plants from the post-beach formation and rocky outcrops (Tab. 1).

Leaf blade thickness did not vary between individuals from the rocky outcrops and the post-beach formation (Tab. 1) In plants from both environments the mesophyll exhibited nine to 14 cell layers (Figs. 4A, B), with an average thickness of $451.7 \mu \mathrm{m}$ and $474.4 \mu \mathrm{m}$ for plants from the rocky outcrops and the post-beach formation, respectively.

In plants from both environments the palisade parenchyma consisted of four to five layers of elongated and juxtaposed chloroplast-rich cells and straight, curved or sometimes oblique anticlinal and periclinal walls (Figs. 4C, D). The inner layers of palisade parenchyma are integrated with shorter cells that comprise the transition to the spongy parenchyma. The spongy parenchyma is organized into 7-10 cell layers, between which are conspicuous intercellular spaces. The cells of the spongy parenchyma are irregular in shape and lie juxtaposed in layers adjacent to the abaxial epidermis (Figs. 4E, F).

Stomata are anomocytic and surrounded by 4-7 ground epidermal cells (Fig. 5A). Cross-sections at the level of the guard cells revealed a prominent cuticular ridge which projects to form two ledges (Fig. 5B). The guard cells occur in small depressions in the epidermis of rocky outcrop plants, whereas in post-beach plants the guard cells are at the same level as epidermal cells (Figs. 4E, F). The sub-stomatal chamber has an irregular shape and can extend up to four

Table 1. Means \pm standard error of parameters measured on leaves of Jacquinia armillaris from post-beach formation and rocky outcrop environments $(*-p<0.05 ; \mathrm{N} / \mathrm{S}-$ not significant).

\begin{tabular}{|c|c|c|c|c|}
\hline \multicolumn{2}{|c|}{ Parameters } & \multirow{2}{*}{$\frac{\text { Rocky Outcrop }}{451.70 \pm 9.78^{\mathrm{a}}}$} & \multirow{2}{*}{$\frac{\text { Post-beach formation }}{474.40 \pm 12.45^{\mathrm{a}}}$} & \multirow{2}{*}{$\frac{\text { Significance }}{\mathrm{N} / \mathrm{S}}$} \\
\hline \multirow{3}{*}{ Leaf } & Thickness ( $\mu \mathrm{m})$ & & & \\
\hline & Length $(\mathrm{cm})$ & $3.43 \pm 0.11^{\mathrm{a}}$ & $2.68 \pm \mathbf{0 . 0 7 ^ { b }}$ & $*$ \\
\hline & Width (cm) & $1.81 \pm 0.06^{\mathrm{a}}$ & $1.35 \pm \mathbf{0 . 0 5 ^ { \mathrm { b } }}$ & * \\
\hline \multirow{2}{*}{ Stomata } & Density (stomata/ $\mathrm{mm}^{2}$ ) & $227.05 \pm 3.81^{b}$ & $234.44 \pm 6.48^{\mathrm{a}}$ & * \\
\hline & Index & $12.74 \pm \mathbf{0 . 2 2 ^ { b }}$ & $13.52 \pm \mathbf{0 . 2 4 ^ { \mathrm { a } }}$ & $*$ \\
\hline \multirow{2}{*}{$\begin{array}{l}\text { Number of glandular } \\
\text { trichomes }\end{array}$} & Abaxial surface & $3.50 \pm 0.14^{\mathrm{a}}$ & $2.87 \pm \mathbf{0 . 1 8 ^ { b }}$ & $*$ \\
\hline & Adaxial surface & $1.43 \pm \mathbf{0 . 1 1 ^ { \mathrm { a } }}$ & $1.09 \pm \mathbf{0 . 0 5 ^ { b }}$ & $*$ \\
\hline \multirow{2}{*}{ Cuticle thickness } & Abaxial surface $(\mu m)$ & $3.28 \pm \mathbf{0 . 1 0 ^ { \mathrm { a } }}$ & $3.45 \pm \mathbf{0 . 1 8 ^ { \mathrm { a } }}$ & $\mathrm{N} / \mathrm{S}$ \\
\hline & Adaxial surface $(\mu m)$ & $3.62 \pm 0.16^{\mathrm{a}}$ & $3.73 \pm \mathbf{0 . 1 9 ^ { \mathrm { a } }}$ & $\mathrm{N} / \mathrm{S}$ \\
\hline
\end{tabular}




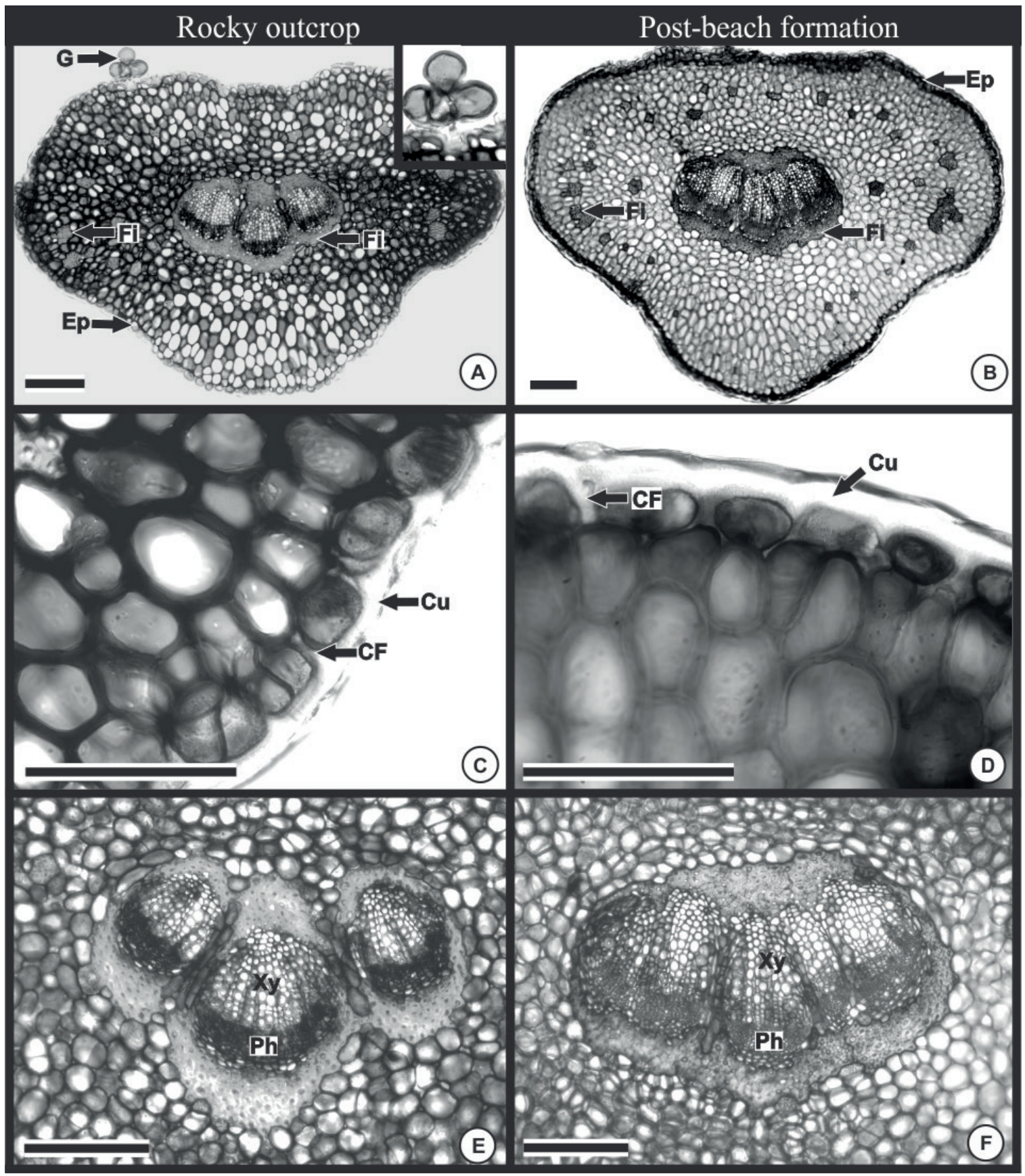

Figs. 1A-F. Cross section of petioles of Jacquinia armillaris from rocky outcrop and post-beach formation. A, C, E. Rocky outcrop plants; B, D, F. Post-beach formation plants; A, B. Overview, with details of the gland in A; C, D. Cortex and epidermis; $\mathbf{E}, \mathbf{F}$. Vascular bundle. Ep = epidermis; G $=$ glandular trichome; $\mathrm{Fi}=$ fibers $\mathrm{Cu}=$ cuticle $\mathrm{CF}=$ cuticular flanges; $\mathrm{Ph}=$ phloem; $\mathrm{Xy}=$ xylem. Bars $=200 \mu \mathrm{m}$.

layers deep into the spongy parenchyma. The stomatal index of leaves of post-beach formation plants was found to be significantly higher than that of rocky outcrop plants (Tab. 1).

Bundles of sclerenchyma fibers are distributed among parenchyma cells of the chlorenchyma (Figs. 4A-F). Fibers are conspicuous on the leaf margin and form a thick, irregular cell sheath around the vascular bundles (Figs. 5C, D).

The midrib is flat on the adaxial surface and convex on the abaxial surface. The ground parenchyma exhibits typical cells with bundles of fibers of different sizes embedded among them. There is a sheath of irregularly thickened fibers in the perivascular region. Vascular bundles are collateral, open and arranged in an arch. The midrib shows secondary growth with poorly developed radial parenchyma of the xylem (Fig. 5D).

Leaf venation is pinnate-camptodromousbrochidodromous (Figs. 6A, B). The midrib is slightly prominent, large at the base and reducing toward the apex where it is barely noticeable. Secondary veins are parallel, alternate, ascending, branching-off from the midrib at angles of 30-40 degrees and forming arches that do not reach the margin (Figs. 6A, B). 


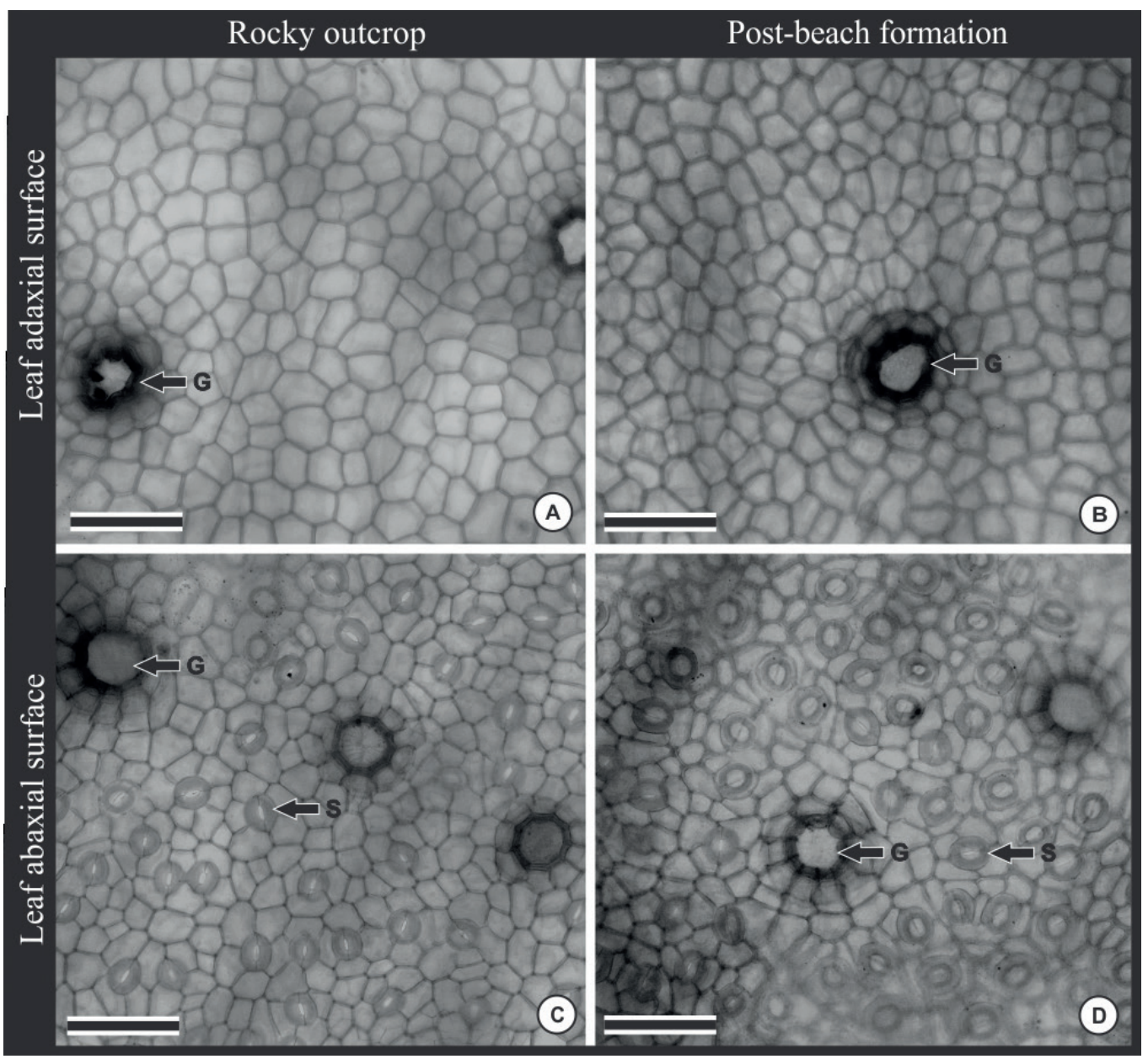

Figs. 2A-D. Frontal view of the adaxial and abaxial surfaces of leaves of Jacquinia armillaris from rocky outcrop and post-beach formation. A, C. Rocky outcrop; B, D. Post-beach formation; A, B. Epidermis of the adaxial surface; C, D. Epidermis of the abaxial surface. $\mathrm{S}=$ stomata; $\mathrm{G}=$ glandular trichome. Bars $=100 \mu \mathrm{m}$.

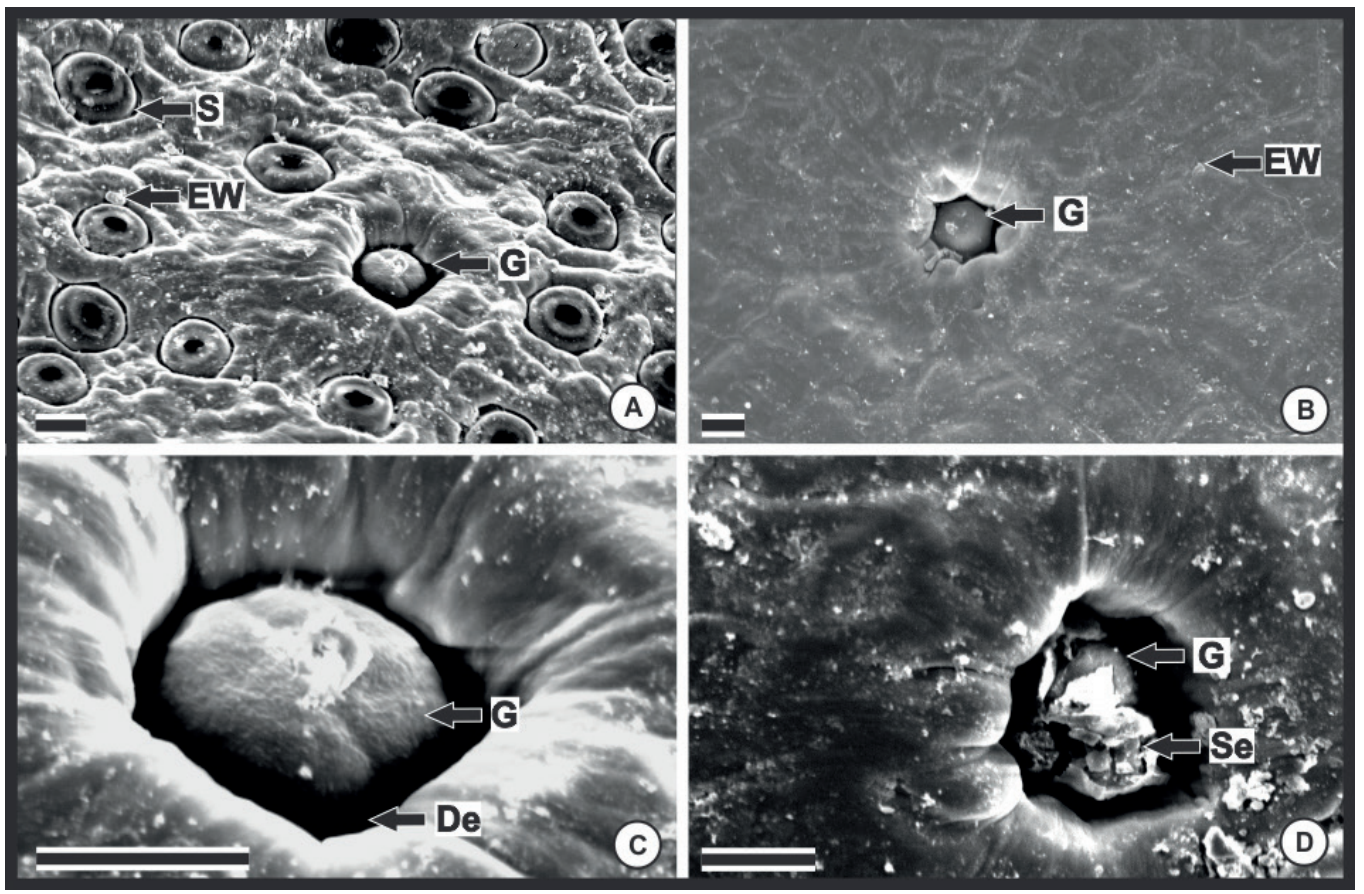

Figs. 3A-D. Scanning electron micrograph of the leaf surface of Jacquinia armillaris. A. Epidermis of the abaxial surface; B. Epidermis of the adaxial surface; $\mathbf{C}$. Glandular trichome; D. Glandular trichome with secretion. $\mathrm{S}=$ stomata; $\mathrm{G}=$ glandular trichome; $\mathrm{EW}=$ epicuticular wax; $\mathrm{Se}=$ secretion; $\mathrm{De}=$ depression. Bars $=20 \mu \mathrm{m}$. 


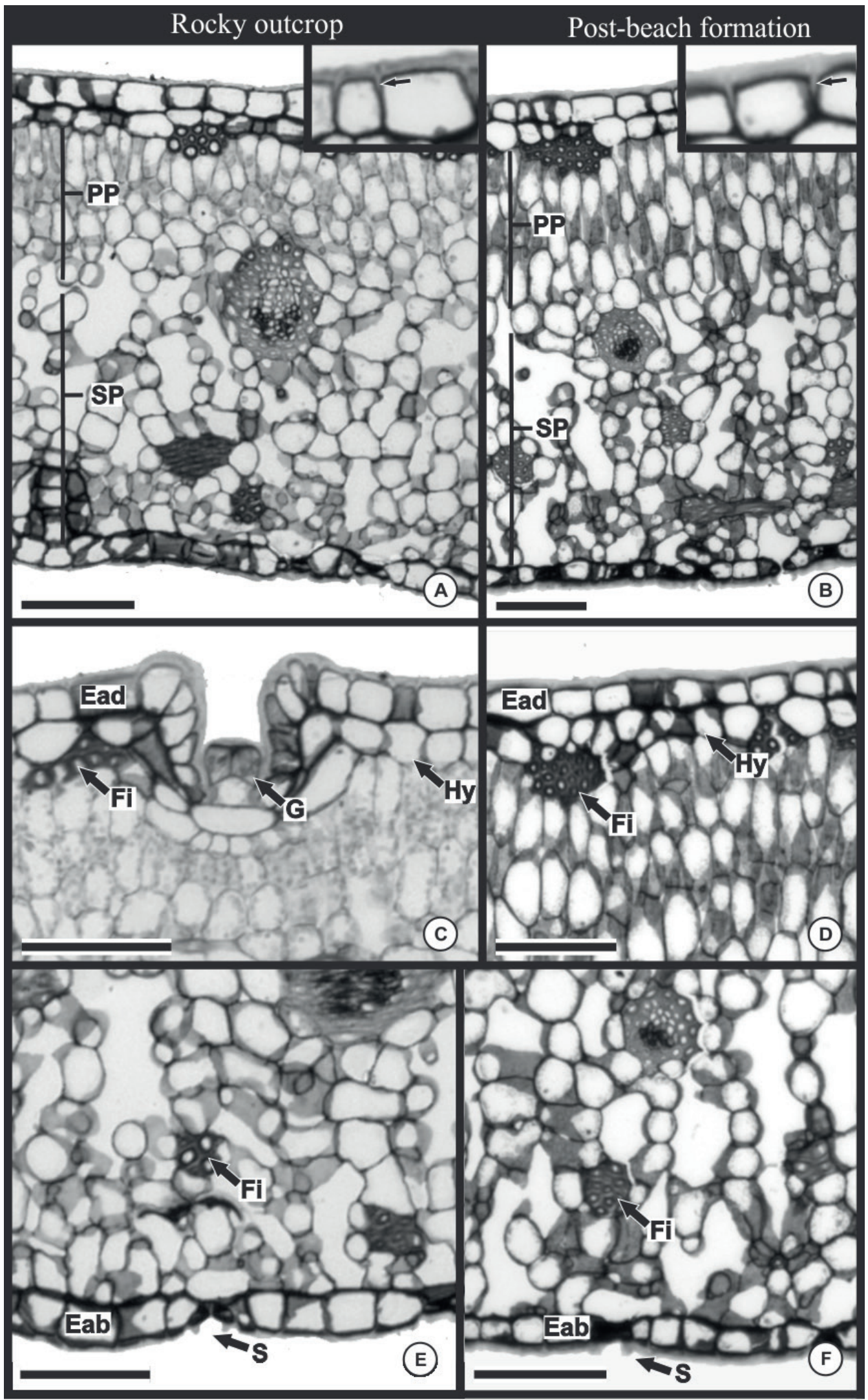

Figs. 4A-F. Cross-section of a leaf blade of Jacquinia armillaris. A, C, E. Rocky outcrop plants; B, D, F. Post-beach formation plants; A, B. Overview of leaf with detail of cuticular flanges (arrow); C, D. Detail of leaf adaxial surface; E, F. Detail of leaf abaxial surface. $\mathrm{PP}=$ palisade parenchyma; SP = spongy parenchyma; $\mathrm{Hy}=$ hypodermis; $\mathrm{S}=$ stomata $\mathrm{G}=$ glandular trichome; $\mathrm{Fi}=$ fibers; Ead = epidermis of the adaxial surface; Eab = epidermis of the abaxial surface. Bars $=100 \mu \mathrm{m}$. 


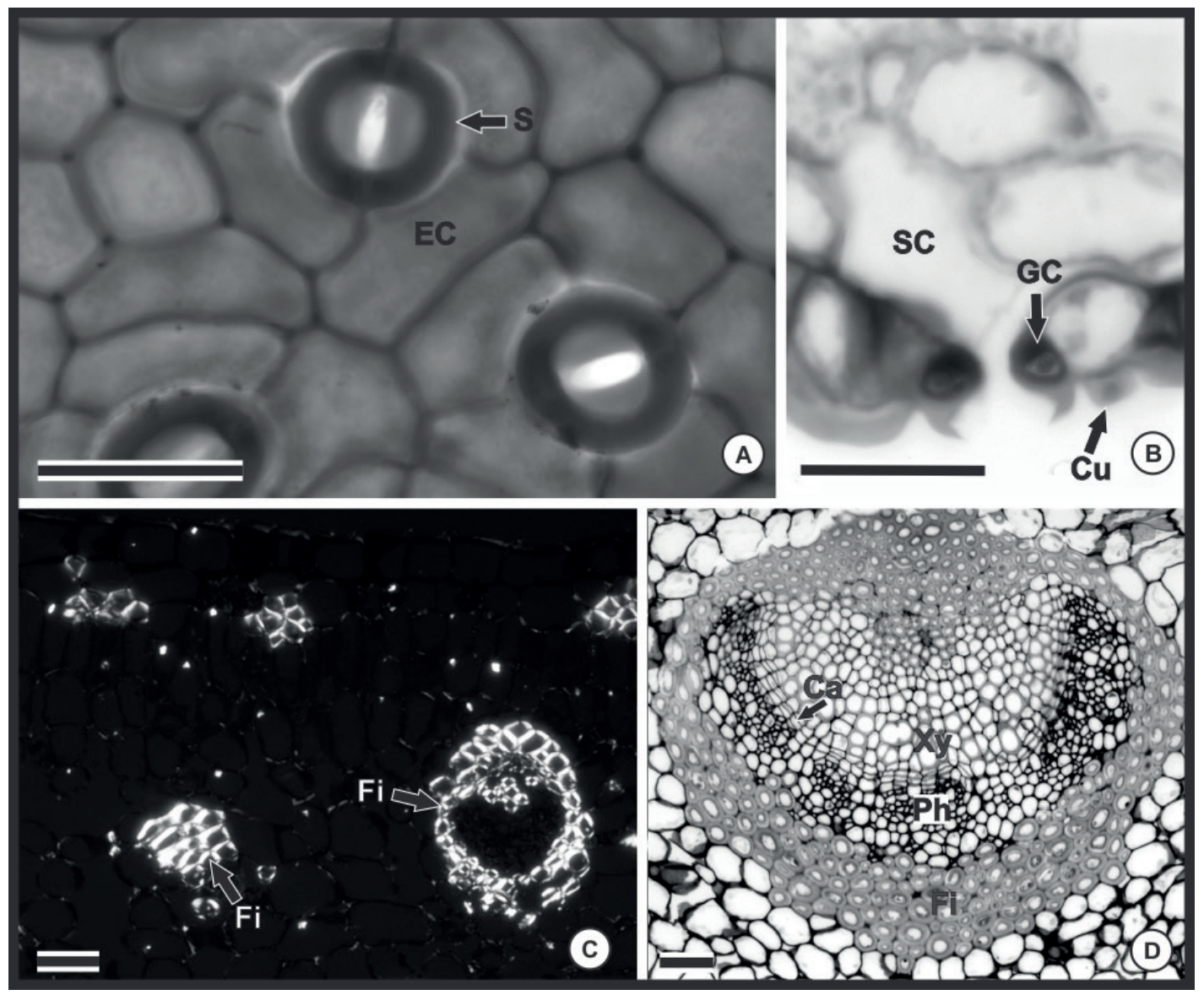

Figs. 5A-D. Anatomical characteristics of the leaf blade of Jacquinia armillaris. A. Frontal view of abaxial surface; B. Cross-section of stomata; C. Cross-section of mesophyll in polarized light; D. Cross-section of midrib. $\mathrm{S}=$ stomata; $\mathrm{EC}=$ epidermal cell; $\mathrm{Cu}=$ cuticle; $\mathrm{GC}=$ guard cell; $\mathrm{SC}$ $=$ subepidermal chamber; $\mathrm{Fi}=$ fibers; $\mathrm{Ca}=$ vascular cambium; $\mathrm{Xy}=\mathrm{xylem} ; \mathrm{Ph}=$ phloem. $\mathrm{Bars}=40 \mu \mathrm{m}$.

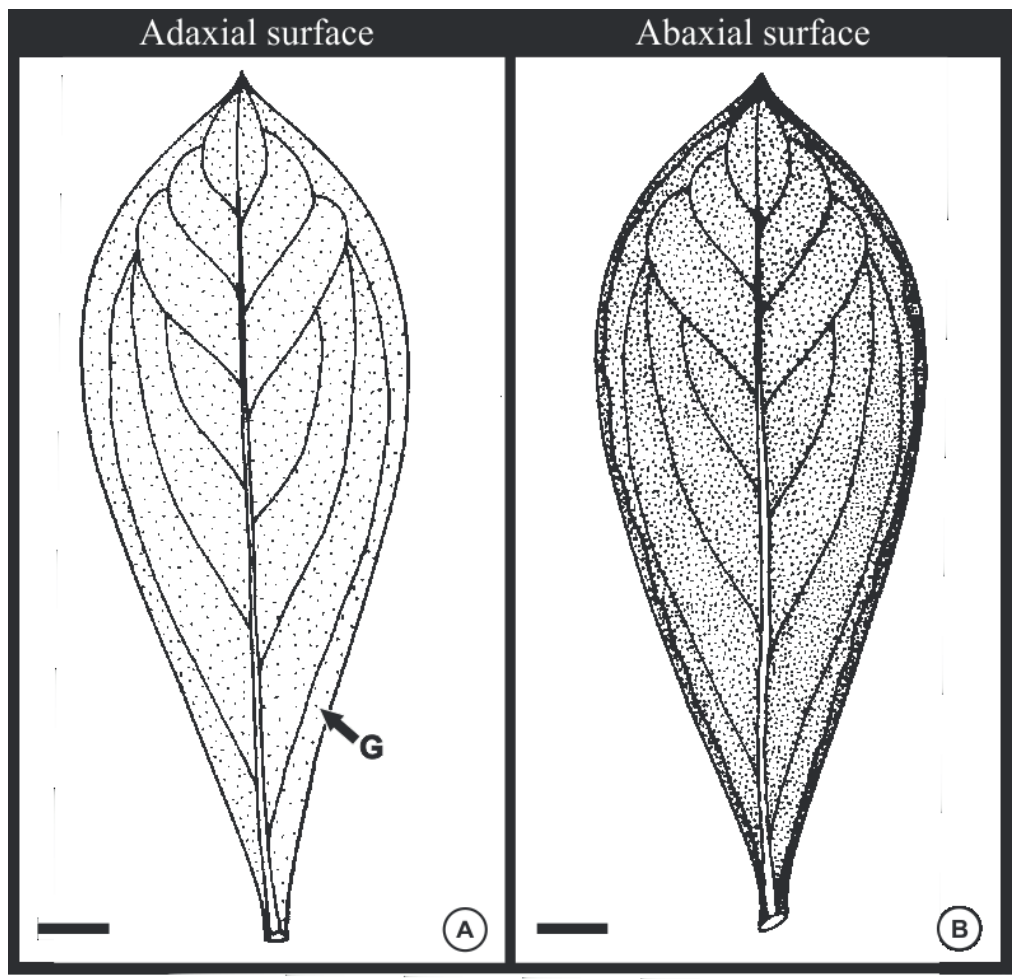

Figs. 6A, B. Pinnate-camptodromous-brochidodromous venation of Jacquinia armillaris. A. Adaxial surface; B. Abaxial surface. G = glandular trichome. Bars $=0.5 \mathrm{~cm}$ 


\section{DISCUSSION}

Leaves from individual plants of Jacquinia armillaris from the two studied environments possess similar anatomical structure, with anatomical characteristics typical of plants in xeric environments. Scarano et al. (2001) pointed out that intense solar radiation, high salinity and water stress are the main limiting factors in Restinga formations. These factors, in association with strong and frequent winds, are characteristic of both the post-beach formation and rocky outcrops and have a direct influence on the adaptive strategies of $J$. armillaris. Some of the features of $J$. armillaris described in this work, such as the thick cuticle, the hypostomatic leaf, the high proportion of mechanical tissues, the hypodermis and presence of epicuticular waxes are characteristics of species of dry environments (Boeger \& Wisniewski 2003).

The thick foliar cuticle of $J$. armillaris may be an adaptation to full sunlight and frequent winds, since it plays an important role in reducing water loss by acting as a barrier to the movement of substances, particularly water, from epidermal cells into the atmosphere (Riederer $\&$ Schreiber 2001). However, the role of cuticle thickness in the reduction of water loss should be interpreted with caution because the chemical composition of the cuticle and environmental temperature can influence the permeability of this layer (Riederer \& Schreiber 2001). Schreiber et al. (1996) demonstrated, in evergreen plants, differential cuticle permeability depending on the developmental conditions of the species, with lower permeability in an epiphytic environment, and changing in xeric and mesic environments, suggesting adaptation to environmental conditions at the cuticular level. Freeman \& Beattie (2008) emphasized that a thick cuticle may increase resistance to the attack of microorganisms and herbivores. In the present study, no signs of the action of microorganisms or herbivores were observed among $J$. armillarisin the field.

O’Toole \& Cruz (1979) stated that stomata on the abaxial surface of leaves can reduce conductance of $\mathrm{H}_{2} 0$ vapor, and are common among species in xeric environments, as was found for J. armillaris in the present study. Rozema (1991) related this distribution of stomata to protection against high evaporation rates, normally due to the low levels of light irradiance and warming that this surface is subjected to (Martin \& Glover 2007). Hypostomatic leaves are common among plants of the Restinga, and have been previously described for Clusia hilariana, Clusia spirictusanctensis (Schneider 1987), Eugenia uniflora (Silva et al. 2005), Eugenia brasiliensis (Donato \& Morretes 2007), Byrsonima sericea, Cordia verbenaceae, Psidium guineense (Silva et al. 2006) and Cyperus maritimus (Martins et al. 2008), among others.

The lower stomatal density observed among plants from rocky outcrops, compared to those from the postbeach formation, is probably associated with the greater size of the leaves of individuals from this area, and may be influenced by humidity. Martins et al. (2010) found a marked reduction in stomatal density for Azadirachta indica when subjected to water stress, corroborating what was observed here in J. armillaris. On rocky outcrops, plants are usually located on the edge of the formation, up to 1 $\mathrm{m}$ away from the sea, while in the post-beach formation they are located up to $10 \mathrm{~m}$ away from the sea, resulting in a more saline humidity for individuals closer to the rocky outcrops. The influence of humidity and temperature on leaf size was confirmed by Camerik \& Werger (1981), leading us to believe that the greater humidity of rocky outcrops may be responsible for the greater epidermal cell expansion, thus leading to lower stomatal density.

With regard to the stomatal index, Cutter (1986) cites that it can vary intraspecifically, and is mainly influenced by light and humidity. The lower stomatal density and index found for plants from the rocky outcrops confirm the presence of stomatal variation in J. armillaris. Casson \& Gray (2008) also found humidity to influence the stomatal index and that it varies among species. Similar results were reported for Scilla nutans, which exhibited a lower stomatal index in leaves of plants developed in an environment with higher humidity (Salisbury 1927).

Fahn \& Cutler (1992) and Körner et al. (1986) related a greater stomata number with the formation of a boundary layer, which decreases the loss of water through transpiration. However, we do not believe this is the case for $J$. armillaris due to its leaves lacking hairs and to the occurrence of strong winds, which inhibit the formation of a boundary layer. Thus, we believe that the high humidity in the rocky outcrops is the determining factor of the lower stomatal index and greater leaf lamina size of the plants in this habitat, since a lower number of stomata can enable greater efficiency in gas exchange, particularly during the day (Allen \& Pearcy 2000).

The location of stomata relative to the level of ordinary epidermal cells, which were observed to be in depressions in the epidermis in plants of rocky outcrops, provides less contact with the dry outside air, thereby reducing water loss by transpiration (Hetherington \& Woodward 2003), which also may explain the higher stomatal index and greater leaf area. Cuticle ledges, which were observed in individuals from both environments, can also help reduce water loss by transpiration since they further decrease contact with the dry outside air.

The glandular trichomes present in the epidermis of leaves of J. armillaris are similar in anatomical structure to that described for salt glands in Glaux maritima L. (Rozema et al. 1977), Phillynea latifolia (Gravano et al. 1998) and Avicennia sp. (Evert 2006). Salt glands are typical of the families Plumbaginaceae, Frankeniaceae and Tamaricaceae, and mangrove plants, such as Avicennia and Laguncularia (Fahn 1979). According to Tomlinson (1994), these trichomes are common among plants in saline environments, and serve to prevent toxic accumulations of $\mathrm{Na}^{+}$and $\mathrm{Cl}^{-}$ions in the tissues of halophytes by secreting excess salts in the form of saline solution. Although glandular secretions of J. armillaris have not been analyzed, it is expected that these are indeed salt glands since the plants grow in a saline environment and the glandular 
structure is comparable to that of salt glands found in plants from similar environments. However, subsequent tests should be carried out to confirm this hypothesis. If true, this would explain the greater number of glandular trichomes in plants of rocky outcrops, which are near the sea, than in plants of the post-beach formation, and thus can be considered an adaptation to salt stress.

On the adaxial surface of leaves of $J$. armillaris, a cell layer comprising cells of a different cell-wall thickness was identified below the epidermis. This layer was found in very young leaves, and originates from the ground meristem. Thus, we suggest that this subepidermal layer is a hypodermis. Tomlinson (1994) considered that this tissue may play a role in the accumulation and storage of salt, thereby providing, in association with salt glands, mechanisms that facilitate the persistence of a species in saline environments. Silva \& Azevedo (2007) reported the presence of a hypodermis in several Restinga species, such as Allagoptera arenaria, Psidium sericea and Clusia hilariana.

The morphological and anatomical features described here for $J$. armillaris may be related to adaptive strategies already known to be employed by plants in xeric environments with high light irradiance and strong winds, such as a thick cuticle, the presence of epicuticular wax, the presence of stomata on the abaxial surface and abundant mechanical tissue. Despite the similarities between the environments of the post-beach formation and rocky outcrops, the proximity of the sea seems to have influenced the plasticity of this species, since areas closer to the sea typically have higher humidity and salinity. These higher levels of humidity and salinity are probably responsible for the lower number of stomata and the larger size of the leaf lamina of individuals from the rocky outcrops. The structure and the location of glandular trichomes of $J$. armillaris lead us to believe they should be classified as salt glands, and since they were found at greater density in plants from rocky outcrops, it seems likely they represent a response to the amount of salty spray that reaches individual plants in this environment.

\section{ACKNOWLEDGEMENTS}

The authors thank Conselho Nacional de Desenvolvimento Científico e Tecnológico for a research productivity scholarship grant to L.C. Silva (309480/20159). We also thank the administration of the Paulo César Vinha State Park for providing access, and Núcleo de Microscopia e Microanálise, Universidade Federal de Viçosa for assist in the acquisition of electronic images.

\section{REFERENCES}

Allen, M.T. \& Pearcy, R.W. 2000. Stomatal behavior and photosynthetic performance under dynamic light regimes in a seasonally dry tropical rain forest. Oecologia 122:470-478.

Andrade, M.A.B. 1967. Contribuição ao conhecimento da ecologia das plantas das dunas do litoral do Estado de São Paulo. Separata do boletim n ${ }^{\circ}$ 305, Faculdade de Filosofia, Ciências e Letras, Universidade de São Paulo 22:3-170.
Arruda, R.C.O., Viglio, N.S.F. \& Barros, A.A.M. 2009. Anatomia foliar de halófitas e psamófilas reptantes ocorrentes na Restinga de Ipitangas, Saquarema, Rio de Janeiro, Brasil. Rodriguésia60:333-352.

Boeger, M.R.T. \& Wisniewski, C. 2003. Comparação da morfologia foliar de espécies arbóreas de três estádios sucessionais distintos de floresta ombrófila densa (Floresta Atlântica) no Sul do Brasil. Revista Brasileira de Botânica 26:61-72.

Boeger, M.R.T. \& Gluzezak, R.M. 2006. Adaptações estruturais de sete espécies de plantas para as condições ambientais da área de dunas de Santa Catarina, Brasil. Iheringia. Série Botânica 61:73-82.

Brito, C.J.F.A. \& Alquini, Y. 1996. A new method for staining botanical material embedded in glycol methacrylate (GMA). Archives of Biology and Technology 39:949-950.

Camerik, A.M. \& Werger, M.J.A. 1981. Leaf characteristics of the flora of the high plateau of Itatiaia, Brazil. Biotropica 13:39-48.

Casson, S. \& Gray, Y.J.E. 2008. Influence of environmental factors on stomatal development. New Phytologist 178:9-23.

Crawford, R.M.M. 2008. Plants at the margin: ecological limits and climate change, Cambridge University Press, Cambridge.494p.

Cutter, E.G. 1978. Plant Anatomy: Cells and Tissues, Part I. William Clowes and Sons, London. 315p.

1986. Anatomia vegetal. Parte I - Células e tecidos. Roca, São Paulo 304p.

Donato, A.M. \& Morretes, B.L. 2007. Anatomia foliar de Eugenia brasiliensis Lam. (Myrtaceae) proveniente de áreas de Restinga e de floresta. Brazilian Journal of Pharmacognosy 17:426-443.

Evert, R.F. 2006. Esau's Plant Anatomy. Wiley-Interscience, New Jersey. $601 \mathrm{p}$.

Fahn, A. 1979. Secretory tissues in plants. Academic Press Inc., London. $302 p$.

Fahn, A. \& Cutler, D.F. 1992. Xerophytes. In Encyclopedia of Plant Anatomy (Spez, ed.). Berlin, GebrüderBorntraeger, p. 87-98.

Freeman, B.C. \& Beattie, G.A. 2008. An overview of plant defenses against pathogens and herbivores. Plant Pathology and Microbiology Publications 94:1-12.

Ghalambor, C.K., McKay, J.K., Carroll, S.P. \& Reznick, D.N. 2007. Adaptive versus non-adaptive phenotypic plasticity and the potential for contemporary adaptation in new environments. Functional Ecology21:394-407.

Gravano, E., Tani, C., Bennici, A. \& Gucci, R. 1998. The ultrastructure of glandular trichomes of Phillyrea latifolia L. (Oleaceae) leaves. Annals of Botany 81:327-335.

Hetherington, A.M. \& Woodward, F.I. 2003. The role of stomata in sensing and driving environmental change. Nature 424:901-908.

Hickey, L.J. 1979. A Revised classification of the architecture of dicotyledonous leaves. In Anatomy of the Dicotyledons (C.R. Metcalfe \& L. Chalk, eds.). Claredon Press, Oxford, p. 25-39.

Instituto Brasileiro do Meio Ambiente e dos Recursos Naturais Renováveis (IBAMA). 2008. Lista Oficial das Espécies da Flora Brasileira Ameaçadas de Extinção. Normative statement n6, 23 de september de 2008. Official Gazette of Brazil.

Jensen, W.A. 1962. Botanical Histochemistry: Principles and Practice. W. H. Freeman and Co., San Francisco. 408p.

Johansen, D.A. 1940. Plant microtechnique. McGraw- Hill., New York. $523 \mathrm{p}$.

Joly, A.B. 2002. Botânica: Introdução à taxonomia vegetal. Companhia Editora Nacional, São Paulo. 777p.

Kollmann, L.J.C.F., Fontana, A.P., Simonelli, M. \& Fraga, C.N. 2007. As Angiospermas ameaçadas de extinção no Estado do Espírito Santo. In Espécies da Flora Ameaçada de Extinção no Estado do Espírito Santo (M. Simonelli \& M. Fraga, eds.). Instituto de Permacultura e Ecovilas da Mata Atlântica, p. 105-140.

Köppen, W. 1948. Climatologia: com um estúdio de los climas de latierra. Fondo de cultura economica, Mexico. 478p.

Körner, C., Bannister, P. \& Mark, A.F. 1986. Altitudinal variation in stomatal conductance, nitrogen content and leaf anatomy in different plant life forms in New Zealand. Oecologia 69:557-588.

Leinz, V. \& Amaral, S.E. 2003. Geologia Geral. Editora Nacional, São Paulo. 399p.

Magnano, L.F.S., Martins, S.V. \& Pereira, O.J. 2011. Heterogeneidade florística das fitocenoses de restingas nos estados do Rio de Janeiro e Espírito Santo, Brasil. Revista Árvore 35(2):245-254. 
Martin, C. \& Glover, B.J. 2007. Functional aspects of cell patterning in aerial epidermis. Current Opinion in Plant Biology 10:70-82.

Martins, M.O., Mansur, R.J., Nogueira, C., Neto, A.D.A. \& Santos, M.G. 2010. Crescimento de plantas jovens de Nim-indicano (Azadirachta indica A. Juss. - Meliaceae) sob diferentes regimes hídricos. Revista Árvore 34(5):771-779.

Martins, S., Machado, S.H. \& Alves, M. 2008. Anatomia e ultraestrutura foliar de Cyperus maritimus Poir. (Cyperaceae): estratégias adaptativas ao ambiente de dunas litorâneas. Acta Botânica Brasilica 22:493-503.

O'Brien, T.P. \& Mccully, M.E. 1981. The study of plant structure: principles and selected methods. Termarcarphy PTY Ltd., Melbourne. 45p.

O'Toole, J.C. \& Cruz, R.T.. 1979. Leaf rolling and transpiration. Plant Science Letters 16:111-114.

Pereira, O.J. 1990. Caracterização fitofisionomica da Restinga de Setiba, Guarapari, E.S. In Anais do II simpósio de ecossistemas da costa sul e sudeste brasileira: estrutura, função e manejo, São Paulo, p. 207-219.

Pereira, O.J. \& Assis, A.M. 2000. Florística da restinga de Camburi, Vitória, ES. Acta Botanica Brasilica 14:99-111.

Porembski, S. 2002. Terrestrial habitat islands as model systems for biodiversity research. In Biodiversidade, conservação e uso sustentável da Flora do Brasil (E.L. Araújo, N.A. Moura, E.V.S.B. Sampaio, L.M.S. Gestinari \& J.M.T. Carneiro, eds.). Universidade Federal Rural de Pernambuco, Recife, p. 158-161.

Riederer, M. \& Schreiber, L. 2001. Protecting against water loss: analysis of the barrier properties of plant cuticles. Journal of Experimental Botany 52:2023-2032.

Rizzini, C.T. \& Mors, W.B. 1995. Botânica econômica brasileira. Âmbito Cultural, Rio de Janeiro. 241p.

Rozema, J. 1991. Growth, water and ion relationships of halophytic monocotyledonae and dicotyledonae, a unified concept. Aquatic Botany 39:17-33.

Rozema, J., Riphagen, I. \& Sminia, T. 1977. Light and electronic microscopical study on the structure and function of the salt gland of Glaux maritima L. New phytologist 79:665-671.

Salisbury, E.J. 1927. On the causes and ecological significance of stomatal frequency, with special reference to the woodland flora. Philosophical Transactions of the Royal Society 216:1-65.

Scarano, F.R. 2002. Structure, function and floristic relationships of plants communities in stressful habitats marginal to Brazilian Atlantic Rainforest. Annals of Botany 90:517-524.
Scarano, F.R., Duarte, H.M., Ribeiro, K.T., Rodrigues, P.J.F.P., Barcellos, B.E.M., Franco, A.C., Brulfert, J., Deleens, E. \& Lüttge, U. 2001. Four sites with contrasting environmental stress in southeastern Brazil: relations of species, life form diversity, and geographical distribution to ecophysiological parameters. Botanical Journal of the Linnean Society 136:345-364.

Schmalhausen, I.I. 1949. Factors of Evolution. Blakiston, Philadelphia. $327 \mathrm{p}$.

Schneider, S.Z. 1987. Anatomia foliar de Clusia hilariana Schlechtendal e Clusia spirictusanctensis G. Mariz Weinberg (Guttiferae) ocorrentes no Estado do Espírito Santo. Acta Botanica Brasilica 1:214-231.

Schreiber, L., Kirsch, T. \& Riederer, M. 1996. Transport properties of cuticular waxes: Ecophysiological relevance for cuticular transpiration. In Trees: contributions to modern tree physiology (H. Rennenberg, W. Eschich \& H. Ziegler, eds.). SPB Academic Publishers, Amsterdam, p. 19-27.

Silva, K.R., Júnior, J.C.F.M. \& Boeger, M.R.T. 2016. Variações fenotípicas em Andira fraxinifolia Benth. (Fabaceae) em duas fitofisionomias de Restinga. Hoehnea 43:237-245.

Silva, L.C. \& Azevedo, A.A. 2007. Anatomia de plantas de Restinga e sua aplicação como ferramenta para a bioindicação. In Ecossistemas costeiros do Espírito Santo: Conservação e restauração (L.F.T. Menezes, F.R. Pires \& O.J. Pereira, eds.). Editora da Universidade Federal do Espírito Santo, Vitória, p. 213-231.

Silva, L.C., Oliva, M.A., Azevedo, A.A., Araújo, J.M. 2006. Responses of Restinga plant species to pollution from an iron pelletization factory. Water, Air, Soil Pollution 175:241-256.

Silva, L.C., Oliva, M.A., Azevedo, A.A., Araújo, J.M. \& Aguiar, R.M. 2005. Micromorphological and anatomical alterations caused by simulated acid rain in Restinga plants: Eugenia uniflora and Clusia hilariana. Water, Air, Soil Pollution 168:129-143.

Stahl, B. 1992. On the identity of Jacquinia armillaris (Theophrastaceae) and related species. Brittonia 44:54-60,

Suguio, K. \& Tessler, M.G. 1984. Planícies de cordões litorâneos do Brasil: origem e nomenclatura. In Restingas: origem estruturas e processos (L.D. Lacerda, eds.). Comissão editorial da Universidade Federal Fluminense, Niterói, p. 195-216.

Tomlinson, P.B. 1994. The Botany of Mangroves. Cambridge University Press., Cambridge. 419p. 